medical and surgical patients-there are no age or disease discriminations between the various types of somatic patients. Why should different criteria apply to different psychiatric conditions? The only consideration for admission surely is that the individual needs treatment.

A subnormal person over the age of 21 who is suffering from a disorder of a nature or degree which warrants his detention in hospital and for whom such care is essential in the interests of his own health or safety, or with a view to the protection of other persons, cannot be given hospital treatment if he cannot be persuaded to enter hospital voluntarily, unless he comes before a court or is transferred from prison or other penal institution by order of the Home Secretary.

Mindful that some of the over 21 age group will become deprived of the necessary parental support and will require special care, the Mental Health Act 1959 should be amended to the effect that in future all persons of any age suffering from mental subnormality who need to be admitted compulsorily into hospital should be dealt with on identical lines with those suffering from mental illness or severe mental subnormality under the present Act.-I am, etc.,

Rudolph PAyne

Little Plumstead Hospital,

Norwich, Norfolk

\section{Treatment of Pediculosis}

SIR,-For several years, we in this Authority have treated children and other members of their families infested with head lice with preparations containing D.D.T.-Suleo emulsion.

In 1967, it was decided to abandon the use of preparations containing D.D.T. because of possible harmful long-term effects of residual D.D.T. solutions. We then started using gamma benzene hexachloride (Lorexane), and this appeared to be very effective. However, in recent months, we are finding that this product is less effective, and feel that head lice are becoming resistant to it.

I would be glad to hear from others on this subject, and to find out if their experience with gamma benzene hexachloride is the same as ours and if they have found an effective alternative preparation for treating infestation by head lice.-I am, etc.,

Flintshire County Counci

G. W. ROBERTS

Mold, Flints

\section{Hypertonic Solutions to Induce Abortion}

SIR,-We read with interest the recent papers reporting the use of intra-amniotic urea (2 January, p. 28) and hypertonic saline (20 February, p. 434) to induce midtrimester therapeutic abortions.

We have found that although urea kills the fetus approximately $20 \%$ fail to abort spontaneously. Hypertonic saline also usually kills the fetus and it has recently been shown that there is a close correlation between the time of fetal death in utero and the initial concentration of salt in the liquor. ${ }^{1}$ However, as there is a failure rate following the use of both these agents and because occasional fatalities have been re- ported following hypertonic saline, we have been interested in finding an additional substance which is both effective and yet free from side effects. One such hypertonic solution to be considered is mannitol, which if inadvertently given intravascularly is only likely to result in a diuresis.

The result of the instillation of $25 \%$ mannitol into the amniotic cavity in a small group of women is seen in the accompanying Table. In each instance liquor was drained off via a polyethylene cannula and then $200 \mathrm{ml} \mathrm{25 \%}$ mannitol instilled. No addi-

TABLE-Induction of Abortion by Intra-amniotic Mannitol

\begin{tabular}{|c|c|c|c|c|c|c|c|}
\hline Age & Parity & $\begin{array}{c}\text { Maturity } \\
\text { (weeks) }\end{array}$ & $\begin{array}{c}\text { Volume } \\
\text { of liquor } \\
\text { aspirated } \\
\text { (ml.) }\end{array}$ & $\begin{array}{c}\text { Volume } \\
\text { of } 25^{\circ} \\
\text { Mannitol } \\
\text { instilled } \\
\text { (ml.) } \\
\end{array}$ & $\begin{array}{l}\text { Outcome } \\
\text { (hours) }\end{array}$ & $\begin{array}{c}\text { Condition } \\
\text { of } \\
\text { fetus }\end{array}$ & Comments \\
\hline 20 & 0 & 20 & 200 & 200 & $\begin{array}{l}\text { Failed } \\
72\end{array}$ & - & $\begin{array}{l}\text { Aborted following hypertonic saline and } \\
\text { intravenous Syntocinon }\end{array}$ \\
\hline 19 & 0 & 18 & 180 & 200 & $\begin{array}{c}\text { Succeeded } \\
36^{1}\end{array}$ & Fresh & - \\
\hline 27 & 2 & 16 & 150 & 200 & $\begin{array}{l}\text { Failed } \\
96\end{array}$ & - & $\begin{array}{l}\text { Uterus larger. Aborted following urea and } \\
\text { artificial rupture of membranes }\end{array}$ \\
\hline 18 & 0 & 19 & 180 & 200 & $\begin{array}{c}\text { Failed } \\
120\end{array}$ & - & $\begin{array}{l}\text { Subsequent intravenous Syntocinon }(2 \\
\text { days) then artificial rupture of membranes. } \\
(400+\text { ml liquor })\end{array}$ \\
\hline 16 & 0 & 16 & 150 & 200 & $\begin{array}{l}\text { Succeeded } \\
52 !\end{array}$ & Fresh & - \\
\hline 21 & 0 & 16 & 160 & 200 & $\begin{array}{l}\text { Succeeded } \\
\quad 60\end{array}$ & Fresh & - \\
\hline 15 & 0 & 17 & 185 & 200 & $\begin{array}{c}\text { Succeeded } \\
30 !\end{array}$ & Fresh & - \\
\hline 23 & 0 & 15 & 150 & 200 & $\begin{array}{l}\text { Failed } \\
72\end{array}$ & - & $\begin{array}{l}210 \mathrm{ml} \text { liquor aspirated at subsequent intra- } \\
\text { amniotic urea. Failed to abort. Vaginal } \\
\text { evacuation. }\end{array}$ \\
\hline 23 & 1 & 16 & 145 & 200 & $\begin{array}{l}\text { Failed } \\
72\end{array}$ & - & Aborted following intravenous Syntocinon \\
\hline 36 & 0 & 16 & 150 & 200 & $\begin{array}{l}\text { Succeeded } \\
45 \frac{1}{4}\end{array}$ & Fresh & - \\
\hline 20 & 0 & 16 & 150 & 200 & $\begin{array}{l}\text { Succeeded } \\
\quad 42\end{array}$ & Fresh & - \\
\hline 20 & 1 & 18 & 175 & 200 & $\begin{array}{l}\text { Failed } \\
72\end{array}$ & - & $\begin{array}{l}390 \mathrm{mlliquor} \text { aspirated at subsequent success- } \\
\text { ful use of hypertonic saline }\end{array}$ \\
\hline
\end{tabular}

The mechanism whereby abortion occurs after the instillation of various substances into the amniotic cavity is not known for certain. It has been suggested that fetal death and suppression of placental endocrine function with a fall in progesterone production precedes the expulsive processes. However, it is unlikely that this is necessarily the case for the fetuses in this study were all fresh, and others have reported successful abortions with live fetuses. Similarly urea may fail even though the fetus may be macerated. It appears that a change in liquor volume is not important, tional measures were taken to encourage abortion for at least 72 hours. If no contractions were then present alternative measures were undertaken. Only $50 \%$ of patients aborted following this regimen and in each instance the fetus appeared fresh suggesting early fetal death is not a necessary prerequisite for abortion. Similarly, though we thought an increase in liquor volume would result and facilitate the process, several of those who failed had evidence of excessive accumulation of liquor three or more days following the procedure. as with mannitol, or decreased, as is usually the case with urea. Until such time as there is more complete knowledge concerning abortion following this techniaue it is unlikely that an agent will be found which is invariably successful and without side effects.-We are, etc.,

Department of Obstetrics and Gynaecology

Kingston Hospital, Surrey

${ }^{1}$ Kovacs, L., Resch, B., Szollosi, J., and Herczeg, J.,
Journal of Obstetrics and Gynaecology of the British Fournal of Obstetrics and Gynaes
Commonwealth, 1970, 77, 1132.

\section{Migraine Variants}

SIR,-The interesting paper of Dr. C. W. M. Whitty (2 January, p. 38) gave a penetrating account of some variants of migraine, including "cluster headache" or periodic migrainous neuralgia. This particular vascular pain syndrome of the head and face is in my opinion rightly classified as a variant of migraine, although it seems to be monophasic, exclusively vasodilatatory, and predominantly localized to the external carotid arterial system. ${ }^{1}$

The first description I have been able to trace is that of Marshall $\mathrm{Hall}^{2}{ }^{2}$ who named a similar syndrome "hemicrania intermittens" or "brow ague". Dr. Whitty's impression that the syndrome is increasing in frequency may not be real, but could emerge from the fact that the diagnosis is made more frequently with increasing clinical awareness of the particular symptoms.

In a period of one and a half years I saw 13 patients with the classical syndrome of periodic migrainous neuralgia and four patients with transitional symptoms to migraine, clinically linking the two syndromes together. ${ }^{1}$ In the three-year period 1967-70 I have observed further 26 patients with migrainous neuralgia. I want to draw attention to five of these patients presenting with chronic migrainous neuralgia. ${ }^{3}$ This parti- 